BNG có nồng độ $\mathrm{NH}_{3}$ máu bình thường [2],[4]. Nhiều yếu tố ảnh hưởng đến độ chính xác của nồng độ $\mathrm{NH}_{3}$. Thứ nhất, một số tác giả cho rằng nông độ $\mathrm{NH}_{3}$ khác nhau khi lấy máu ở những vị trí khác nhau (động mạch, tĩnh mạch). Thứ hai, trong quá trình lấy máu nếu sử dụng garô hoặc bệnh nhân nắm chặt bàn tay thì có thể làm tăng $\mathrm{NH}_{3}$ máu giả tạo. Thứ ba, nồng độ $\mathrm{NH}_{3}$ còn phụ thuộc vào thời gian xử lý mẫu máu. Kết quả có thể không chính xác nếu mẫu máu không được đặt ngay trong bồn đá hoặc không được phẩn tích trong vòng 15 phút sau khi lấy [3],[8]. Ngay cả việc lấy và xử lý mẫu máu thích hợp, nồng độ NH3 cũng không chẩn đoán BNG một cách đáng tin cậy. Nghiên cứu của Gundling [8] ghi nhận khoảng $60 \%$ bệnh nhân BNG độ III có nồng độ $\mathrm{NH}_{3}$ máu bình thường. Nói cách khác, những bênh nhân với nồng độ $\mathrm{NH} 3$ máu bình thường có thể bị BNG và những bệnh nhân với nồng độ $\mathrm{NH}_{3}$ máu tăng có thể có chức năng nhận thức bình thường. Do đó, nồng độ $\mathrm{NH}_{3}$ máu không phải là một công cụ có giá trị để chẩn đoán BNG. BNG là một chẩn đoán lâm sàng sau khi đã loại trừ các nguyên nhân khác gây rối loạn chức năng não, chẩn đoán không phụ thuộc nồng độ $\mathrm{NH}_{3}$ máu.

\section{KẾT LUẬN}

BNG độ III chiếm đa số và thường xuất hiện nhiều triệu chứng cùng lúc. Trong đó, các triệu chứng như nói lảm nhảm, dấu run vẫy, rối loạn giấc ngủ, mất định hướng thời gian và không gian xuất hiện nhiều. Cận lâm sàng như hemoglobin giảm, tiểu cầu giảm, albumin máu giảm, PT kéo dài và bilirubin máu tăng gợi ý xơ gan tiến triển. $\mathrm{NH}_{3}$ máu tăng chiếm đa sổ ở các mức độ bệnh não gan.

\section{TÀI LIÊU THAM KHẢO}

1. Bajaj JS, Schubert CM, Heuman DM. Persistence of cognitive impairment after resolution of overt hepatic encephalopathy. Gastroenterology 2010; 138:2332-2340.

2. Ferenci $\mathbf{P}$, Lockwood $\mathbf{A}$, Mullen K. Hepatic encephalopathy - definition, nomenclature, diagnosis, and quantification: final report of the working party at the 11th World Congresses of Gastroenterology, Vienna. Hepatology 2002; 35: 716-721.

3. Montagnese S, De Pitta $C$, De Rui M. Sleepwake abnormalities in patients with cirrhosis. Hepatology 2014;59:705-712

4. Umeshverma JR-I, Gupta PK, Virmani SK. Clinical spectrum of precipitating factors of hepatic encephalopathy in patient of liver cirrhosis. IOSR Journal of Dental and Medical Sciences. 2018;17(7):17-22.

5. Maqsood S, Saleem A, Iqbal A. Precipitating factors of hepatic encephalopathy: experience at Pakistan Institute of Medical Sciences Islamabad. Journal of Ayab Medical College Abbottabad. 2006; 18(4):57-61.

6. Lê Hà Xuân Sơn. Khảo sát mối tương quan giữa các yếu tố thúc đẩy và tử vong trên bệnh nhân Bệnh não gan loại C. Luận văn tốt nghiệp bác sĩ nội trú. 2015. Đại học Y khoa Phạm Ngọc Thạch, tr. 1-70

7. Mumtaz K, Ahmed US, Ábid S. Precipitating Factors and The Outcome of Hepatic Encephalopathy in Liver Cirrhosis. Journal of the College of Physicians and Surgeons Pakistan. 2010; 20(8): 514-518.

8. Gundling F, Zelihic E, Seidl H. How to diagnose hepatic encephalopathy in the emergency department. Annals of Hepatology. 2013;12:108-114.

\title{
MỐI LIÊN QUAN GIỮA NỒNG Độ CA19-9, CEA HUYẾT THANH VớI MộT Số YẾU Tố Ở BÊ̂NH NHÂN UNG THƯ ĐƯờ'NG MẬT
}

\section{TÓM TẮT.}

Đăt vấn đề: Unq thư đườnq mât (CCA) là môt khối u ác tính nquyên phát bắt nquồn từ các tế bào biểu mô ốnq mât. Bênh thườnq phát hiên ở qiai đoan muôn và tiên lương xấu của khối u này dẫn đến nhu câuu cấp thiết tìm hiểu về dấu ấn sinh học. Mục tiêu: Đánh giá mối liên quan giữa nồng độ CA 19-9, CEA

\footnotetext{
${ }^{1}$ Trường Đại học Y Dược Thái Nguyên 2Bệnh viện Trung ương Quân đội 108 Chịu trách nhiệm chính: Đồng Đức Hoàng Email: Drhoang85@gmail.com Ngày nhận bài: 23.11.2020 Ngày phản biên khoa học: 30.12 .2020 Ngày duyệt bài: 8.01.2021
}

\section{Đồng Đức Hoàng ${ }^{1}$, Nguyễn Xuân Quýnh ${ }^{2}$}

huyết thanh với một số yễu tố ở bệnh nhân ung thư đường mât. Phương pháp: Nghiển cứu cắt ngang được thực hiện ở 52 bênh nhân CCA. Bệnh nhân được làm các xét nighiệm miê̂n dịch, chụp CT bung, nội sơi, xa hình xương đánh giá di cắn. Chẩn đoán xác định bằng sinh thiết và xét nghiệm mô bệnh học bắng phương pháp nhuộm Hematoxylin-Eosin. Kết quả: Tỉ lệ tăng CA $19-9$ là $63.5 \%$. Tỉ lệ tăng CEA là 44.2\%. CA 19-9 cao nhất $(756.2 \pm 871.3)$ ơ giai đoạn 3 theo TNM, $\mathrm{p}=0.9$. CEA cao nhất $(184.6 \pm 371.2)$ ở giai đoan 3 theo TNM, $p=0.3$. CA 19-9 của ung thư đường mật trong gan là $715.3 \pm 605.7$, ngoài gan $436.2 \pm 517.5, p=0.2$. CEA của ung thư đường mật trong gan là $88.0 \pm 268.9$, ngoài gan $17.6 \pm 23.4, p=$ 0.4. Nônng độ CA $19-9$ và kích thước khối u có mối liên hệ tương quan tuyến tính yếu, $r=0.22(r<0.3), p=$ 0.11 . Nồng độ CEA và kích thước khối u có mối liên hệ 
tương quan tuyến tính yếu, $r=0.19(r<0.3)$, $p=$ 0.17. Nồng đô CA 19-9 trung bình của những bênh nhân được cắt gan là $278.4 \pm 522.6$ thấp hơn nhiều so với những bệnh nhân không thể cắt gan $756.8 \pm$ $582.4, p=0.02$. Nồng đô̂ CEA trung bình của những bênh nhân được cắt gan là $49.8 \pm 122.1$ thấp hơn so với những bệnh nhân không thể cắt gan $82.6 \pm 268.0$, $\mathrm{p}=0.7$. Kết luân: Nồng đô CA 19-9 ở bênh nhân cắt gan thấp hơn so với bệnh nhân điều trị bằng hóa chất, xạ trị, điều trị giảm nhẹ. Chưa thấy mối liên quan giữa CEA và giai đoạn TNM, phân loại ung thư đường mật, chỉ đinh điều tri.

Tư khóa: Ung thư đường mật, Carbohydrate antigen 19-9, Carcinoembryonic antigen

\section{SUMMARY}

CARBOHYDRATE ANTIGEN 19-9 (CA 19-9) AND CARCINOEMBRYONIC ANTIGEN (CEA) SERUM MARKERS ARE ASSOCIATED WITH SOME FACTORS OF CHOLANGIOCARCINOMA

Background: Cholangiocarcinoma (CCA) is a primary malignant tumor that originates in bile duct epithelial cells. The disease is often detected at late stage and the bad prognosis of this tumor leads to an urgent need to learn about biomarkers. Aim: to evaluate the relationship between serum CEA, CA 19-9 levels and factors in CCA patients. Methods: A prospective study was carried out in 52 CCA patients. Patients were immunized Carbohydrate antigen 19-9 (CA 19-9), Carcinoembryonic antigen (CEA); abdominal CT scan, endoscopy, bone scintigraphy to assess metastases. Diagnosis of CCA was determined by biopsy and histopathological examination by Hematoxylin-Eosin staining method. Results: The rate of increase in CA $19-9$ was $63.5 \%$. The CEA increase rate was $44.2 \%$. CA $19-9$ was highest (756.2 \pm 871.3 ) in TNM stage $3, p=0.9$. The highest CEA $(184.6 \pm 371.2)$ in TNM stage $3, p=0.3$. Mean CA $19-9$ of intra hepatic CCAwas $715.3 \pm 605.7$, extra hepatic CCA $436.2 \pm 517.5, p=0.2$. The mean CEA of intra hepatic CCAwas 88.0 \pm 268.9 , extra hepatic CCA $17.6 \pm 23.4, p=0.4$. CA $19-9$ serum level and tumor size had a weak linear correlation, $r=0.22(r<0.3)$, $p$ $=0.11$. CEA serum level and tumor size had a weak linear correlation, $r=0.19(r<0.3), p=0.17$. Mean CA $19-9$ of resectable patients was $278.4 \pm 522.6$ much lower than that of unresectable patients $756.8 \pm$ 582.4, $\mathrm{p}=0.02$. Mean CEA of resectable patients was $49.8 \pm 122.1$, lower than that of unresectable patients $82.6 \pm 268.0, p=0.7$. Conclusion: CA 19-9 levels in resectable patients were lower than patients treated with chemotherapy, radiation and palliative care. No association between CEA and TNM stage, biliary cancer classification, indications for treatment.

Keyword: Cholangiocarcinoma, Carbohydrate antigen 19-9, Carcinoembryonic antigen

\section{I. ĐĂT VẤN ĐỀ}

Ung thư đường mật (CCA) là khối u ác tính nguyên phát bắt nguồn từ tế bào biểu mô ống mật[1]. CCA chiếm tỉ lệ xấp xỉ 10 đến $25 \%$ của tất cả các bệnh ung thư gan, tỷ lệ mới mắc tăng rõ rệt trên toàn thế giới trong nhiều thập kỷ qua. Ở Thái Lan, Đông Bắc Á, CCA là một vấn đề sức khỏe nghiêm trong. Tỷ lê mắc CCA được theo sau bởi các khu vực khác của Đông Nam Á và Trung Quốc. Ở Anh và xứ Wales, từ năm 19971998, CCA gây ra gần 1.000 ca tử vong mỗi năm. Tỷ lê mắc CCA ở Hoa Kỳ trong giai đoan từ 1992 đến 2000 tăng 4\% hàng năm[2]. Chẩn đoán CCA hiện nay đòi hỏi sự kết hợp của xét nghiệm, chẩn đoán hình ảnh, nội soi đường mật và mô bệnh học. Tuy nhiên, việc phát hiện ở giai đoạn muộn và tiên lượng xấu của khối u này đã dẫn đến nhu cầu cấp thiết tìm hiểu về dấu ấn sinh học để chẩn đoán sớm CCA[3].

CA 19-9 là một dấu ấn huyết thanh cho ung thư tụy, CCA và các khối u ác tính khác có độ nhạy và độ đặc hiêu dưới mức tối ưu[1]. CA 19-9 không chỉ được sử dụng để chẩn đoán mà còn để tiên lượng. Một phân tích tổng hợp đã được thực hiện để xác định vai trò tiên lượng của nồng đồ CA 19-9 trong huyết thanh trước phẫu thuật với thời gian sống thêm của bệnh nhân CCA. Kết quả cho thấy CA 19-9 tăng có tiên lượng xấu hơn. Trong CCA rốn gan, một nhóm nhỏ của CCA, sự kết hợp của nồng độ huyết thanh CA 19-9 và CEA tăng cao có liên quan đến giai đoạn khối u và giảm thời gian sống thêm[1]. Liêu CA 19-9 và CEA tăng trong máu có liên quan đến những yếu tố nào? Chúng tôi tiến hành nghiên cứu này nhằm mục tiêu: Đánh giá mối liên quan giữa nồng độ CEA, CA 19-9 huyết thanh với một số yếu tố ở bếnh nhân ung thư đường mật.

\section{II. ĐỐI TƯợNG VÀ PHƯƠNG PHÁP NGHIÊN CỨU \\ 2.1.Đối tượng nghiên cứu}

- Tiêu chuẩn chon đối tượng nghiên cứu: Bệnh nhân được chẩn đoán CCA bằng kết quả mô bệnh học.

- Tiêu chuẩn loại trừ: bênh nhân có HCC kết hơp, ung thư đường mât di căn từ cơ quan khác, bểnh nhân di ứng thuốc cản quang, bênh nhân không sinh thiết được, không đồng ý tham gia nghiên cứu.

2.2.Thời gian, địa điểm nghiên cứu

- Thời gian nghiên cứu: Từ tháng 10 năm 2017 đến tháng 4 năm 2020.

- Địa điểm nghiên cứu: Bệnh viện Trung ương quân đội 108.

2.3.Phương pháp nghiên cứu

- Phương pháp nghiên cứu cắt ngang, đánh giá mối liên quan giữa các yếu tố.

- Thiết kế tiến cứu.

\subsection{Cõ̃ mẫu và cách chọn mẫu}


*Công thức cõ̃ mẫu: sử dụng công thức tính cõ̃ mẫu ước tính 1 tỉ lệ của quần thể:

$$
\mathrm{n}=Z_{(1-\alpha / 2)}^{2} \frac{p q}{d^{2}}
$$

Trong đó: $Z_{(1-a / 2)}$ : hệ số giới hạn tin cây, chọn mức tin cậy $95 \% \rightarrow Z_{(1-a / 2)}=1,96$. d: độ chính xác mong muốn, chọn $\mathrm{d}=0,1 \cdot \mathrm{p}=0,122$ (theo nghiên cứu của Cardinale $V$, tỉ lệ bênh nhân CCA do bất kì nguyên gì là $12.2 \%[2]$. Ảp dụng công thức tính được $n=41.1$ bệnh nhân. Chúng tôi chọn ngẫu nhiên được 52 bệnh nhân đủ tiêu chuẩn vào nghiên cứu.

\subsection{Các bước tiến hành nghiên cứu}

- Hỏi thông tin nhân khẩu học, khám thấy có triệu chứng của CCA.

- Các bệnh nhân được làm các xét nghiệm công thức máu và đông máu bằng máy Cell Dyn 3700 (Abbot) tại khoa Huyết học. Xét nghiệm sinh hóa bằng máy Olympus Au 640 tại khoa Sinh hóa. Xét nghiệm CA 19-9, CEA bằng phương pháp ELISA, thực hiện tại khoa Miễn dịch. Chụp CT ổ bụng bằng máy Brivo CT385. Chụp xạ hình xương toàn thân (Whole Body Scan) 3 giờ sau tiêm tĩnh mach $15 \mathrm{mCi}$ Tc99mMDP bằng hệ thống GE Medical System. Nội soi dạ dày, đại tràng bằng máy Olympus.

- Bệnh nhân có khối u tại gan được sinh thiết theo quy trình: gây tê ngoài da bằng Lidocain $2 \%$, dùng súng Fustgun, dưới hướng dẫn của máy siêu âm Logiq S7, chọc kim 16 Gauge vào khối u lấy bệnh phẩm dài khoảng $1 \mathrm{~cm}$, đường kính $1 \mathrm{~mm}$, cố định bằng dung dịch Formol, xét nghiệm và chẩn đoán mô bệnh học bằng phương pháp nhuộm Hematoxylin-Eosin.

- Đánh giá tổn thương di căn từ đường mật chủ yếu trên hình ảnh $C T$, nếu có di căn đến ống tiêu hóa sẽ tiến hành nội soi sinh thiết làm xét nghiệm mô bệnh học để chẩn đoán.

- Thu thập số liệu theo mẫu bệnh án chung thống nhất.

\subsection{Chỉ tiêu nghiên cứu}

* Giới: nam, nữ.

* Xét nghiệm miễn dịch:
- CA 19-9 tăng khi > $129 \mathrm{IU} / \mathrm{ml}$.

- CEA tăng khi > 5ng/ml.

* Chỉ tiêu trên hình ảnh CT:

- Vị trí khối u: thùy gan phải, thùy gan trái, 2 thùy.

- Số lượng u: đếm số u trên hình ảnh chụp CT.

- Kích thước u: Tổng đường kính lớn nhất của tất cả các khối u trên CT.

- Di căn: phổi, hạch, xương, ống tiêu hóa, phúc mạc, tụy.

*Chỉ tiêu về nội soi tiêu hóa:

- Vị trí khối u, số lượng khối u, bề mặt khối u.

*Giai đoạn TMN phân loại theo AJCC (American Joint Committee on Cancer)[4].

*Ung thư đường mật trong gan là tổn thương từ trên $2 \mathrm{~cm}$ tính từ ngã ba đường mật tạo bởi ống gan trái, ống gan phải và ống gan chung tới tiểu quản mật. Ung thư đường mật ngoài gan là đoạn từ $2 \mathrm{~cm}$ từ ngã ba đường mật đến bóng Vater.

2.7.Xử lý số liệu. Số liệu được xử lý bằng phần mềm thống kể y học SPSS 22.0. Phân tích các số liệu bằng thuật toán thống kê mô tả tần số các biến Frequencies, Descriptive. So sánh giá trị trung bình nhiêuu nhóm bằng phân tích oneway ANOVA, tính mối tương quan giữa 2 biến định lượng bằng phân tích Bivariate, có ý nghĩa thống kề khi $p<0,05$.

\section{KẾT QUẢ NGHIÊN CỨU}

Bảng 1: Đặc điểm chung của đôî tượng nghiên cứu

\begin{tabular}{|c|c|c|c|}
\hline \multicolumn{2}{|c|}{ Đắc điếm } & $\mathbf{n ( 5 2 )}$ & $\mathbf{\%}$ \\
\hline \multirow{2}{*}{ Giới } & Nam & 31 & 59.6 \\
\cline { 2 - 4 } & Nữ & 21 & 40.4 \\
\hline \multicolumn{2}{|c|}{ Tuối trung bình } & \multicolumn{2}{|c|}{$60.98 \pm 10.29$} \\
\hline CA & Bình thường & 19 & 36.5 \\
\cline { 2 - 4 } $19-9$ & Tăng & 33 & 63.5 \\
\hline \multirow{2}{*}{ CEA } & Bình thường & 29 & 55.8 \\
\cline { 2 - 4 } & Tăng & 23 & 44.2 \\
\hline
\end{tabular}

Nhận xét: Nam giới có tỉ lệ $59.6 \%$ cao hơn so với nữ giới $40.4 \%$. Tuổi trung bình của đối tượng nghiên cứu là $60.98 \pm 10.29$. Tỉ lệ tăng $\mathrm{CA}$ 19-9 là 63.5\%. Tỉ lệ tăng CEA là 44.2\%.

Bảng 2: Môi liên quan giữa nồng độ CA 19-9, CEA và giai đoạn TNM

\begin{tabular}{|c|c|c|c|c|c|}
\hline \multirow{2}{*}{ Giai đoạn TNM } & \multirow{2}{*}{$\mathrm{n}$} & \multicolumn{2}{c|}{ CA 19-9 } & \multicolumn{2}{c|}{ CEA } \\
\cline { 3 - 6 } & & Mean \pm SD & Min, Max & Mean \pm SD & Min, Max \\
\hline Giai đoạn I & 12 & $645.3 \pm 593.8$ & $2.0 ; 1200$ & $44.3 \pm 105.7$ & $1.7 ; 373.0$ \\
\hline Giai đoạn II & 17 & $657.9 \pm 524.9$ & $0.8 ; 1200$ & $12.5 \pm 33.3$ & $1.2 ; 141.4$ \\
\hline Giai đoạn III & 5 & $756.2 \pm 871.3$ & $2.0 ; 2044$ & $184.6 \pm 371.2$ & $2.0 ; 848.0$ \\
\hline Giai đoạn IV & 16 & $676.5 \pm 636.0$ & $2.0 ; 2021$ & $135.6 \pm 375.3$ & $1.3 ; 1500$ \\
\hline \multicolumn{2}{|c|}{$\mathrm{p}=0.9$} & \multicolumn{2}{c|}{$\mathrm{p}=0.3$} \\
\hline
\end{tabular}

Nhận xét: Nồng độ CA 19-9 trung bình cao nhất (756.2 \pm 871.3) ở giai đoạn 3 theo TNM, nhưng không có sự khác biệt so với các giai đoạn khác, $p=0.9$. Nồng độ CEA trung bình cao nhất (184.6 \pm 
371.2) cũng ở giai đoạn 3 theo TNM, nhưng cũng không khác biệt so với các giai đoạn khác, $\mathrm{p}=0.3$.

Bảng 3: Mối liên quan giữa nồng độ CA 19-9, CEA và phân loại ung thư

\begin{tabular}{|c|c|c|c|c|c|}
\hline \multirow{2}{*}{ Phân loại } & \multirow{2}{*}{$\mathbf{n}$} & \multicolumn{2}{|c|}{ CA 19-9 } & \multicolumn{2}{|c|}{ CEA } \\
\hline & & Mean \pm SD & Min, Max & Mean \pm SD & Min, Max \\
\hline Ung th & 42 & \pm 605.7 & $0.8 ; 2044$ & $88.0 \pm 268.9$ & $1.2 ; 1500$ \\
\hline Ung thư ngoài gan & 8 & $436.2 \pm 517.5$ & $5.1 ; 1200$ & $17.6 \pm 23.4$ & $1.2 ; 70$ \\
\hline & & \multicolumn{2}{|c|}{$p=0.2$} & \multicolumn{2}{|c|}{$p=0.4$} \\
\hline
\end{tabular}

Nhận xét: Nồng độ CA 19-9 trung bình của ung thư đường mật trong gan là $715.3 \pm 605.7$ cao hơn so với ung thư đường mật ngoài gan $436.2 \pm 517.5$, nhưng không có ý nghĩa thống kê $p=0.2$. Nồng độ CEA trung bình của ung thư đường mật trong gan là $88.0 \pm 268.9$ cao hơn so với ung thư đường mật ngoài gan $17.6 \pm 23.4$, nhưng cũng không có ý nghĩa thống kê với $p=0.4$.

Bảng 4: Mối liên quan giữa nồng độ CA 19-9, CEA và chỉ định điều trị

\begin{tabular}{|c|c|c|c|c|c|}
\hline \multirow{2}{*}{ Chỉ định điều trị } & \multirow{2}{*}{$\mathbf{n}$} & \multicolumn{2}{c|}{ CA 19-9 } & \multicolumn{2}{c|}{ CEA } \\
\cline { 3 - 6 } & & Mean \pm SD & Min, Max & Mean \pm SD & Min, Max \\
\hline Cắt gan & 9 & $278.4 \pm 522.6$ & $0.8 ; 1200$ & $49.8 \pm 122.1$ & $1.7 ; 373.0$ \\
\hline Không cắt gan & 41 & $756.8 \pm 582.4$ & $2.0 ; 2044$ & $82.6 \pm 268.0$ & $1.2 ; 1500$ \\
\hline \multicolumn{2}{|c|}{$p=0.02$} & \multicolumn{2}{c|}{$p=0.7$} \\
\hline
\end{tabular}

Nhận xét: Nồng độ CA 19-9 trung bình của những bệnh nhân được cắt gan là $278.4 \pm 522.6$ thấp hơn nhiều so với những bệnh nhân không thể cắt gan $756.8 \pm 582.4$, sự khác biệt này có ý nghĩa thống kê $p=0.02$. Nồng độ CEA trung bình của những bệnh nhân được cắt gan là $49.8 \pm$ 122.1 thấp hơn so với những bệnh nhân không thể cắt gan $82.6 \pm 268.0$, nhưng sự khác biệt này không có ý nghĩa thống kê $\mathrm{p}=0.7$.

Biểu đồ 1: Môi liên quan giữa nồng độ CA 19-9 và kích thước khôi u

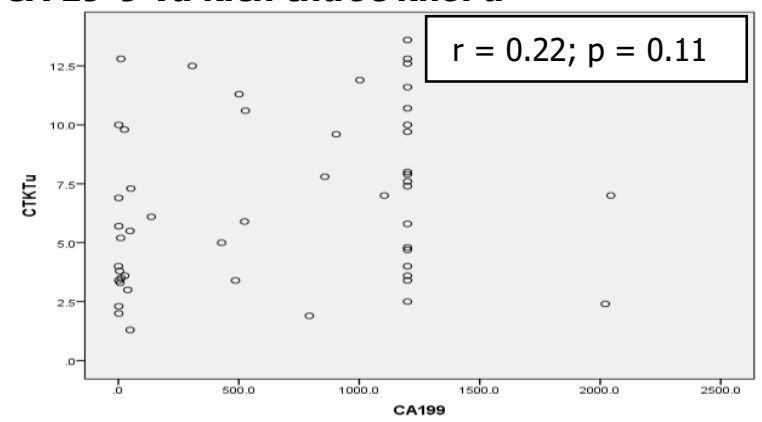

Nhận xét: Giá trị $r=0.22(r<0.3)$ và nhìn hình dạng đồ thị thì thấy giữa nồng độ CA 19-9 và kích thước khối u có mối liên hệ tương quan tuyến tính yếu. Mối liên hê giữa hai biến này không có ý nghĩa thống kê với $\mathrm{p}=0.11$.

Biểu đồ 2: Mối liên quan giữa nồng độ CEA và kích thước khối u

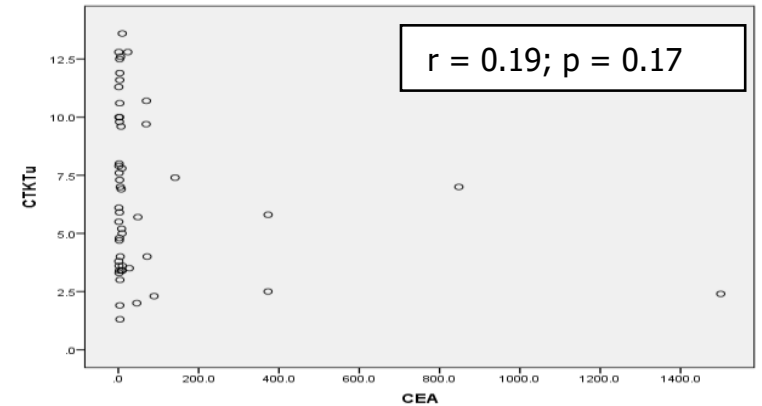

Nhận xét: Giá trị $r=0.19(r<0.3)$ và nhìn hình dạng đồ thị thì thấy giữa nồng độ $C E A$ và kích thước khối u có mối liên hệ tương quan tuyến tính yếu. Mối liên hệ giữa hai biến này không có ý nghĩa thống kê với $p=0.17$.

\section{BÀN LUÂN}

Nghiên cứu này của chúng tôi được tiến hành trên nhóm bệnh nhân có khá nhiều yễu tố nguy cơ gây ung thư đường mật như viêm gan virus, xơ gan, hút thuốc, sỏi mật, đái tháo đường. Các bênh mạn tính này thường diễn biến lâu năm nển tuổi trung bình của nhóm nghiên cứu khá cao và các bệnh này gặp ở cả hai giới nhưng vẫn gặp nhiều hớn ở nam. Kết quả nghiên cứu của Ramage cũng thây tỉ lệ nam giới cao hơn so với nữ[5]. Tất cả các bệnh nhân được xét nghiệm CA 19-9 và $C E A$, chụp cắt lớp vi tính tuy nhiên để chẩn đoán xác định thì chúng tôi tiến hành sinh thiết toàn bộ bệnh nhân. Độ nhạy và độ đặc hiệu của CA 19-9 với giá trị cắt là $100 \mathrm{U} / \mathrm{ml}$, tương ứng là 68 và $87 \%[1]$. Sử dụng ngưỡng giá trị $5 \mathrm{ng} / \mathrm{mL}$ cho CEA và $200 \mathrm{U} / \mathrm{mL}$ cho CA 19-9, độ nhạy của từng chất đánh dấu trong việc phân biệt ung thư biểu mô với không ung thư là $53,3 \%$ đối với CEA và $60 \%$ đối với CA $19-9$. Độ đặc hiệu là $86,3 \%$ cho CEA và $91 \%$ cho CA 19 9[5]. Kết quả xét nghiệm dấu ấn miễn dịch nói chung có độ chính xác là không cao, tuy nhiên các nghiên cứu vẫn khuyến cáo rằng $C A$ 19-9 và CEA trong huyết thanh là một bổ sung hữu ích cho các xét nghiệm có sẵn để chẩn đoán phân 
biệt ung thư đường mật[6].

Hình ảnh chụp cắt lớp vi tính ổ bụng ở nhóm bệnh nhân này cũng không hoàn toàn điển hình, kết quả chụp vừa để xác định số u, vị trí và di căn để đánh giá giai đoạn bệnh. Kết quả phân tích của nghiên cứu này cho thấy nồng độ $C A$ 19-9 ở các giai đoạn theo TNM không có sự khác nhau nhiêu. Các bệnh nhân ở giai đoạn sớm cũng đã có nồng độ CA 19-9 rất cao. Singh và CS có nói rằng $\mathrm{CA}$ 19-9 tăng cao có thể liên quan đến tình trạng tắc mật nhưng vẫn cần nghiên cứu thêm[1]. Về nồng độ CEA thì chúng tôi lại thấy tăng ở giai đoạn I, tăng ít hơn ở giai đoạn II, ở giai đoạn III và IV thì tăng khá cao, tuy nhiên những sự khác nhau này không có ý nghĩa thống kê khi đánh giá. Tương tự khi so sánh nồng độ các dấu ấn giữa ung thư đường mật trong gan và ngoài gan thì thấy sự khác biệt giữa hai nhóm cũng không có ý nghĩa.

Chúng tôi phân tích tương quan giữa nồng độ dấu ấn với kích thước khối u thì thấy tương quan giữa nồng độ CA 19-9 và kích thước khối u có mối liên hệ tương quan tuyến tính yếu, giá trị $r=$ $0.22(r<0.3)$. Mối liên hệ giữa hai biến này không có ý nghĩa thống kể với $\mathrm{p}=0.11$. Nồng độ CEA và kích thước khối u cũng có mối liên hệ tương quan tuyến tính yếu, giá trị $r=0.19(r<$ 0.3). Mối liên hê giữa hai biến này không có ý nghĩa thống kê với $p=0.17$. Điều này có thể thây rằng không phải u cứ to lên thì nồng độ dấu ấn miễn dịch sẽ tăng theo. Chúng tôi thẩy có những bênh nhân u chỉ $1,9 \mathrm{~cm}$ nhưng nồng độ CA 19-9 là $793 \mathrm{U} / \mathrm{mL}$, có bệnh nhân u 2,4cm nồng độ CA 19-9 là 2021U/mL, CEA là $1500 \mathrm{ng} / \mathrm{mL}$.

CCA phát triển chậm nhưng di căn cao, thường được phát hiện ở giai đoạn không thể phát hiện được, do đó hầu hết bệnh nhân có tiên lượng xấu với tỷ lệ sống trung bình là 6 trận12 tháng. CCA không nhạy cảm với hóa trị liệu, liệu pháp miễn dịch, xạ trị và phẫu thuật cắt bỏ hiện đang là liệu pháp hiệu quả duy nhất[3]. Số bệnh nhân chúng tôi chỉ định cắt u là 9 , các bệnh nhân khác phần lớn điều trị hóa chất và giảm nhẹ có 3 bệnh nhân bệnh ở giai đoạn muộn được trả về chăm sóc tại nhà. Các bệnh nhân cắt gan đều chỉ có 1 khối ù, kích thước dao động từ 3 đến $9,8 \mathrm{~cm}, 2$ bệnh nhân có hạch rốn gan và không di căn. Trong số này chỉ có 2 bênh nhân có tăng CA 19-9, 2 bệnh nhân tăng CEA. Sasaki chỉ ra rằng $C A$ 19-9 càng cao thì thời gian sống thêm sau phẫu thuật càng ngắn. CEA, một dấu ấn khối u mạnh mẽ̃ trong nhiêu khối u ác tính đường tiêu hóa, đã được chú ý ngày càng tăng như là dấu hiệu khối u tiềm năng trong các khối u ác tính ở gan[7]. Trong một nghiên cứu, CEA có tính dự đoán tốt hơn cho thời gian sống thêm sau khi cắt bỏ ung thư đường mật so với CA 199[8].

\section{KẾT LUẬN}

Sau nghiên cứu chúng tôi có một số kết luận như sau: Tỉ lệ tăng CA $19-9$ là $63.5 \%$. Tỉ lệ tăng CEA là $44.2 \%$.

Nồng độ CA 19-9 và CEA không có sự khác biệt có ý nghĩa ở các giai đoạn TNM.

Nồng độ CA 19-9 và CEA không có sự khác biệt có ý nghĩa giữa ung thư đường mật trong và ngoài gan.

Nồng độ CA 19-9 có mối liên hệ tương quan tuyến tính yếu với kích thước khối $u, r=0.22(r$ $<0.3), p=0.11$. CEA có mối liên hệ tương quan tuyến tính yếu với kích thước khối u $r=0.19(r$ $<0.3), \mathrm{p}=0.17$.

Nồng độ CA 19-9 thấp hơn có ý nghĩa ở bệnh nhân điêu trị bằng cắt gan, $\mathrm{p}=0.02$.

Nồng độ CEA thấp hơn nhưng không có ý nghĩa ở bệnh nhân cắt gan, $\mathrm{p}=0.7$.

\section{TÀI LIÊU THAM KHẢO}

1. Zeng $X$, Tao H. (2015). Diagnostic and prognostic serum marker of cholangiocarcinoma. Oncol Lett., 9(1): 3-8.

2. Cardinale $\mathbf{V}$, Semeraro $R$, Torrice $A$, et al. (2010). Intra-hepatic and extra-hepatic cholangiocarcinoma: New insight into epidemiology and risk factors. World J Gastrointest Oncol., 2(11): 407-416.

3. Malaguarnera G, Paladina I, Giordano $M$, et al. (2013). Serum Markers of Intrahepatic Cholangiocarcinoma. Dis Markers., 34(4): 219-228.

4. Sasaki K, Margonis G.A, Andreatos N, et al. (2018). Serum tumor markers enhance the predictive power of the AJCC and LCSGJ staging systems in resectable intrahepatic cholangiocarcinoma. HPB (Oxford). 20 (10): 956-965.

5. Ramage J.K, Donaghy A, Farrant J.M, et al. (1995). Serum Tumor Markers for the Diagnosis of Cholangiocarcinoma in Primary Sclerosing Cholangitis. Gastroenterology, 108:865-869

6. Qin X.L, Wang Z.R, Shi J.S, et al. (2004). Utility of serum CA19-9 in diagnosis of cholangiocarcinoma: in comparison with CEA. World Journal of Gastroenterology, 10(3):427-432.

7. Jaklitsch M, Petrowsky H. (2019). The power to predict with biomarkers: carbohydrate antigen 19-9 (CA 19-9) and carcinoembryonic antigen (CEA) serum markers in intrahepatic cholangiocarcinoma. Translational Gastroenterology and Hepatology, 20: 956-65.

8. Loosen S.H, Roderburg C, Kauertz K.L, et al. (2017). CEA but not CA19-9 is an independent prognostic factor in patients undergoing resection of cholangiocarcinoma. Scientific Reports., 7: 16975. 